\title{
Casting of Polyacrylamide/Poly (vinyl alcohol) Reinforced by Carbon Nano-Wire for Using into Proton Exchange Membrane Fuel Cell
}

\section{M.M. El-Toony}

National Center For Radiation Research and Technology, Atomic Energy Authority, Egypt, P.O. Box 29- Nasr City, Cairo, Egypt. 11370

\begin{abstract}
AMMA irradiations pose very important role for finally cross-linking, poly (vinyl alcohol) (PVA) and acrylamide (AAm) with different ratios. The addition of $0.3 \%$ carbon nano-wire into the cast mixture was well mixed prior to being exposure to the irradiation doses (kGy). It was found that; $10 \mathrm{kGy}$ was the optimum dose in order to attain accepted physical properties for the fuel cell's application. Phosphorylation of the casted membranes was performed to improve their specifications for the desired application. Characterizations of the casted membranes were carried out using Fourier transformer infra-red (FTIR), thermal gravimetric analysis (TGA) and scanning electron microscopy (SEM) for their investigations chemically, thermally and morphologically respectively. Studying the properties of the membranes was performed using ion exchange capacity (IEC), water uptake and tensile strength for testifying their availability into the proton exchange membrane fuel cell (PEMFC). Proton conductivity was measured (maximum value was $8.1 \times 10^{-2} \mathrm{~S} / \mathrm{cm}$ ) and free volumes sizes were evaluated using positron annihilation lifetime spectroscopy $(P A L S)$. The casted membrane confirmed their capability for using into PEMFCs by measuring the fuel cell performance and durability (up to 500 hours) comparing to compressed Nafion ${ }^{\circledR} 1110$.
\end{abstract}

Keywords: Casting, Gamma irradiation, Acrylamide, Poly (vinyl alcohol), Carbon nano-wire, Fuel cell.

\section{Introduction}

PEMFC, eco-friendly energy source, have received attention to replace combustion engines. Also, PEMFC has various applications containing vehicles, spaceship, mobile phones, and power plants. Polymer electrolyte membrane used in PEMFC is one of core parts of PEMFC and is closely related to cell performance. Nafion has a good proton conductivity and mechanical properties. However, there are several drawbacks the most important one is the Nafion's high cost [1-4]. The performance of PEMFC is known to be influenced by many structural and operational parameters such as membrane characteristics [5, 6], membrane-electrode assembly (MEA) [7, 8] reactants temperature and relative humidity [9-11].

PVA is one of the most commonly used polymers in different applications because of its chemical stability and excellent film forming ability [12]. Nevertheless, PVA membrane has some properties which become as obstacles to perform the fuel cell application as it is, with its high solubility in water and extremely hydrophilic pattern as a membrane substance. To overcome these constraints, PVA can be modified by blending [13], cross-linking [14] or grafting [15]. Casting is a powerful and well-established method used to improve the performance of the PVA membranes into the PEMFC applications. Actually, it can be ensured that; the PVA-based membranes are believed to be promising components for PEMFC.

PAAm hydrogels have been extensively studied for biomedical applications, such as drug delivery systems [16-18]. Due to different polymeric networks of the PAAm, it has been used in various fields $[19,20]$. Interpenetrating polymeric networks of PAAm / PVA has been prepared with

Correspondig auhtor e-mail: toonyoptrade@yahoo.com

Phone: 20201003823267

DOI: 10.21608/ejchem.2017.1276.1071

C2017 National Information and Documentation Centre (NIDOC) 
the PAAm gel by the formation of inter-polymer complex [19]. PVA has been chemically modified by crosslink co-polymerization of acrylamide (AM) in an aqueous solution of PVA and finally crosslinking the co-polymer to produce a full interpenetrating network (FIPN) membrane [21].

Carbon, a monolayer of $\mathrm{sp}^{2}$ hybridized carbon atoms organized in honeycomb lattice, is a semi-metal (zero gap semi-conductor) [22]. Due to their chemical, electrical, optical and mechanical properties, they can be employed in an exceptionally wide application range, including sensing, smart textiles, catalysis, battery technology or composite reinforcement [23-25]. Finite termination of carbon into the membrane results in opening a band gap in carbon nano-wire structures, that is inversely proportional to the width [26].

In this work casting of phosphorylated PAAm and similar for PVA with different ratios and $0.3 \%$ carbon nano-wire was carried out. Characterization of the membranes using FTIR, TGA, and SEM. Some parameters were measured such as $I E C$, water uptake, proton conductivity, membrane thickness and tensile strength. The membrane proved their applicability into the PEMFC and their durability up to 500 hours compared to Nafion 1110.

\section{Experimental}

\section{Materials}

Acrylamide, carbon nano-wire phosphonic acid and hypophosphorous were kindly provided by Aldrich, England. PVA (Mw. 14000) were provided by Merck (Germany). All chemicals were of analytical grade and used without further purification.

\section{Membrane synthesis}

PVA was dissolved in deionized (DI) water by stirring at $90{ }^{\circ} \mathrm{C}$ to obtain a $5 \%(\mathrm{w} / \mathrm{w})$ solution. Then, $\mathrm{H}_{3} \mathrm{PO}_{2}$ : PVA mass ratio 6:1 was prepared by mixing aqueous solutions of $0.5 \mathrm{M} \mathrm{H}_{3} \mathrm{PO}_{2}$ and $5 \%$ PVA. After vigorous stirring of the mixtures at room temperature for 30 minutes, the solutions were cast into molds (polystyrene petri dishes) $[27,28]$.

AAm was dissolved by bi-distilled water for a $1 / 2$ hour at $70{ }^{\circ} \mathrm{C}$. It was placed in sealed glass ampoules with 5\% diluted phosphonic acid. The phosphonic acid was diluted with co-solvents namely methylene chloride and methanol with a 1:1 volume ratio then pouring them with ratio

Egypt. J. Chem. 60, No. 5 (2017)
10,20 and $30 \%$ into the petri dishes. Adding $0.3 \%$ carbon nano-wire into the cast mixture was performed. The cast components were well mixed using magnetic stirrer for $1 / 2$ hour. Membrane thickness was adjusted to $50+/-2 \mu \mathrm{m}$ and measured by a digital micrometer (Flower China). Different gamma irradiation (Co-60) doses $(5,10,15$ and $20 \mathrm{kGy}$ ) were used to ensure finally crosslinking and complete phosphorylation prior to solvent evaporation (24 hours at room temperature). The prepared membranes were stored in a dry atmosphere after carefully detaching from the petri dishes [29]. Before characterization, the membranes were washed in deionized water to get rid of un-reacted phosphonic acids until neutrality was reached. The prepared membranes were stored in a dry atmosphere [3].

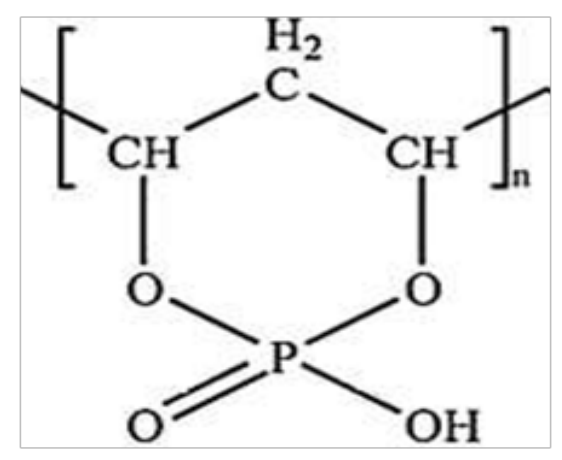

Fig. 1. The suggested structure of phosphorylated PVA [30].

Ion exchange capacity (IEC) and degree of substitution

IEC values of the casted polymers were measured using a typical titration method. The dried membranes in the protonic form were immersed into $25.00 \mathrm{~mL}$ of $3 \mathrm{M}$. $\mathrm{NaCl}$ solution for $24 \mathrm{~h}$. A large excess of $\mathrm{Na}^{+}$in the solution ensured nearly complete ions have exchanged. Then, $10.00 \mathrm{~mL}$ of the $3 \mathrm{M}$. $\mathrm{NaCl}$ solution containing the released $\mathrm{H}^{+}$was titrated against $0.05 \mathrm{M} \mathrm{NaOH}$ solution using phenolphthalein as indicator. The $I E C$ was calculated using the following equation:

$I E C_{\text {exp }}=\frac{0.05 \times V_{\text {NaOH }} \times n}{----------} \quad\left(\mathrm{m}_{\text {equiv }} / \mathrm{g}\right) \ldots . . .(1)$

where $V_{\mathrm{NaOH}}(\mathrm{mL})$ is $0.05 \mathrm{M} \mathrm{NaOH}$ solution's volume used for titration. $n$ is the factor corresponding to the ratio of the amount of $\mathrm{NaCl}$ solution taken to immerse the polymer $(25.00 \mathrm{~mL})$ 
to the amount used for titration $(10.00 \mathrm{~mL})$, which is $2.5 . W_{\text {dry }}(\mathrm{g})$ is the dry weight of the polymer electrolyte membrane in the protonic form [31].

\section{Water uptake and proton conductivity}

The prepared membranes were immersed in DI for different times (hours) intervals till attaining constant weight. The water uptake was calculated as the following:

Water uptake $=\frac{\left(W_{\text {wet }}-W_{\text {dry }}\right)}{--------}$ x100

where $\mathrm{W}_{\text {wet }}$ and $\mathrm{W}_{\text {dry }}$ are the membrane weights in the wet and dry states, respectively. Proton conductivity was determined by impedance spectroscopy measurement using a LCR meter, Herioki, Japan at $20 \mathrm{~Hz}$ to $1 \mathrm{MHz}$ frequency range. The samples were hydrated in water at 25 - $\mathrm{C}$ overnight before the measurements. The highfrequency intercept on the real axis of the Nyquist plot was used to calculate the membranes' proton conductivity. The ionic conductivity $(\sigma)$ was calculated according to the following equation:

$\mathrm{L}$

$\sigma\left(\Omega^{-1} \mathrm{~cm}^{-1}\right)=$

RA

where $\mathrm{L}$ is the thickness of the membrane sample, A or $\left(\pi r^{2}\right)$ is the sample surface area and $R$ is the resistance [32].

\section{Positron annihilation lifetime spectroscopy}

The PALS of the membranes were determined by detecting the prompt Y-ray $(1.28 \mathrm{MeV})$ from the nuclear decay that accompanies the emission of a positron from the ${ }^{22} \mathrm{Na}$ radioisotope and the subsequent annihilation Y-rays $(0.511 \mathrm{MeV})$. A conventional fast-fast coincidence circuit of PAL spectrometer with a time resolution 240 Ps was used to record all PAL spectra. The PAL spectra containing $1.5 \times 10^{6}$ counts were analyzed into three components $(\tau 1, \tau 2$, and $\tau 3)$ and their intensities (I1, I2, and I3) using PALS fit program [33].

\section{Fuel cell performance}

The (MEAs) were fabricated by hot-pressing the anode and the cathode to the membrane at 200 ${ }^{\circ} \mathrm{C}$ and 1500 psi for 90 seconds. The Pt loading in the anode and the cathode were 0.3 and $0.5 \mathrm{mg}$ $\mathrm{cm}^{-2}$, respectively. The active area of MEAs was $5 \times 5 \mathrm{~cm}^{2}$. The MEA was placed in a single cell using stainless steel as the end plates and stainless mesh as the current collectors. To check the selfhumidifying effect of the Nafion-1110 and cast
(PVA and PAAm with 0.3 carbon nano-wire) membrane, the single cell was kept running with dry $\mathrm{H}_{2}$ and $\mathrm{O}_{2}$. Pure hydrogen and oxygen were used as a fuel and an oxidant with a flow of $0.2 \mathrm{~L} /$ min. regulated by a mass flow controller (Brooks). The MEAs were evaluated with a commercial fuel cell test system (Compu-cell, GT, Electrochem) running a single cell test. The cell voltages and power densities were recorded at different current densities after a stable cell performance was maintained [34]. The membranes were treated by boiling in $3 \% \mathrm{H}_{2} \mathrm{O}_{2}$ and $0.5 \mathrm{M} \mathrm{H}_{2} \mathrm{SO}_{4}$ in deionized water to completely remove all impurities before the experiment was carried out [35].

\section{Equipment}

- The cast membrane (10/90/0.3\%) functional groups were studied using a Mattson 1000, Pye-Unicam, England.

- The cast membrane (10/90/0.3\%) surface investigation and magnification were carried out by SEM on a JEOL-JSM-5400 (Japan). The magnification was $30 \mathrm{kV} \mathrm{X1000.}$

The casted membrane's (10/90/0.3\%) thermal stability was analysed with a Shimadzu TGA-50, Japan. The heating rate was $10{ }^{\circ} \mathrm{C} /$ minute in a nitrogen gas atmosphere

\section{Results and Discussion}

\section{Theoretical approach}

This workaims to achieve cheapmembrane with highly electrical conductivity, environmentally friend and having high stability. Phosphorylating the poly (vinyl alcohol) and similar for acrylamide were carried out. Adding phosphorylated PVA to phosphorylated PAAm with carbon nano-wire and mixing well was performed prior to being irradiated. Gamma irradiation has a potential role for complete phosphorylate the PAAm and PVA and finally cast membranes crosslinking. The carbon nano-wire has a serious role for membrane reinforcement, gasses passage control, and electrical conductivity improvement. This work has been illustrated in Fig. 2.

\section{Membrane characterization}

The evidence of co-polymerization and network formation by characterizing the casted membrane (PVA / PAAm with 0.3 carbon nanowire).

In the FTIR spectrum shown in Fig. 3, the peak at $3400 \mathrm{~cm}^{-1}$ is due to the $\mathrm{O}-\mathrm{H}$ stretching 


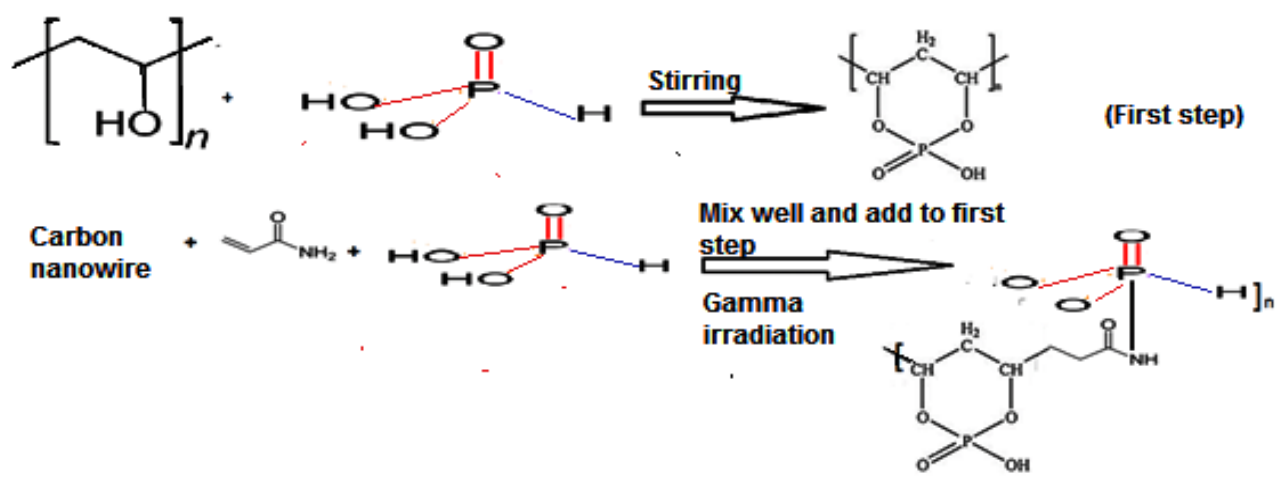

Fig. 2. The schematic work illustration.

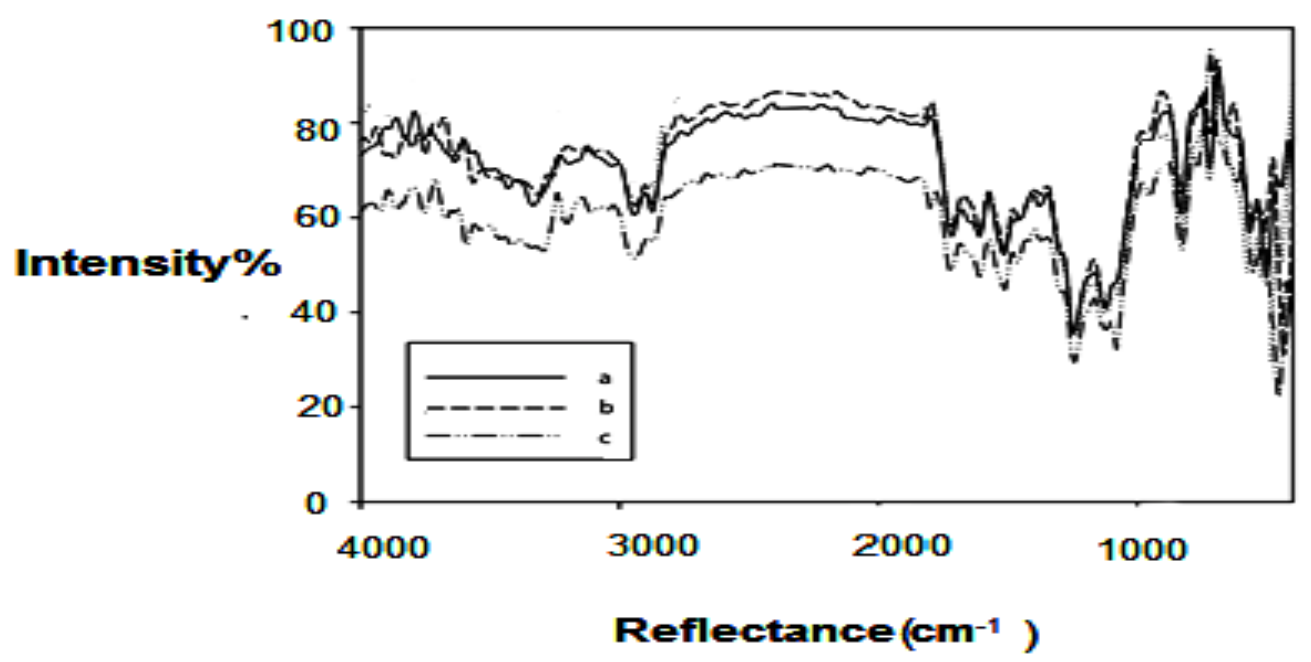

Fig 3. FTIR spectra of phosphorylated poly (vinyl alcohol) / phosphorylated poly (acrylamide) with 0.3 carbon nano-wire casted membrane at $10 \mathrm{kGy}$ radiation dose. a) 70\% PVA: 30\% PAAm, b) 80\% PVA: 20\% PAAm, c) 90\% PVA: 10\% PAAm by weight.

vibration band. Some broadness in $\mathrm{OH}$, due to intermolecular hydrogen bonding between the hydroxyl groups, participated along with the chains of the co-polymer network structure. Phosphorylates display bands due to the PO stretching vibration mainly in the $900-1200 \mathrm{~cm}^{-1}$ range, especially the $(\mathrm{POH})$ at approximately $925 \mathrm{~cm}^{-1}$ and $\mathrm{PO}_{2}^{2-}$ at approximately $970 \mathrm{~cm}^{-1}$ vibrations [36]. The absorption band at 3433 $\mathrm{cm}^{-1}$ is attributed to the vibration corresponding to the NH groups from the crosslinking, while the asymmetric valence vibration from 2926 $\mathrm{cm}^{-1}$ is assigned to the $\mathrm{CH}_{2}$ groups included in the macromolecular chains and crosslinking [37]. In addition, increasing the intensity of the stretching vibration band of the C-C group at $1450 \mathrm{~cm}^{-1}$ provides evidence of a crosslinking co-polymerization reaction [38]. Increase phosphorylated PVA at the cast membranes, increase the peaks intensity and express their importance role for the PEMFC applications.

Surface Morphology study

Scanning electron microscope of phosphorylated PVA/ phosphorylated PAAm cast membranes with $0.3 \%$ carbon nanowire was illustrated in Fig.4.

Figure 4(a) showed obvious differentiated two polymers shared into the cast membranes. The small cube-like structure with bright, whitish 
color and bigger matrix with dark grayish color can be distinguished. Figure 4(b) showed less distinguishable polymers' compartments of the casted membranes. Bigger non-geometrical structural were obviously seen. Large pores and grooves have been irregularly distributed onto the prepared membrane's surface. Figure 4(c) illustrated nearly non-distinguishable cast membrane's compartments. The membrane has wavy, smooth surface with small pores and channels. This illustration showed the optimum compatibility of the three kinds of the prepared membranes. These observations recommend it to be successfully applied into PEMFC. There is no dots aggregation onto the polymer matrix which ensured well distribution (homogenous distribution) of carbon nanowire into the casted membranes.

\section{Thermal gravimetric analysis}

The adding 0.3 carbon nanowire into the $90 \%$ PVA and $10 \%$ PAAm cast membrane improved their thermal stability as seen in Fig. 5 and Table 1. The thermogram could be divided into 5 divisions.

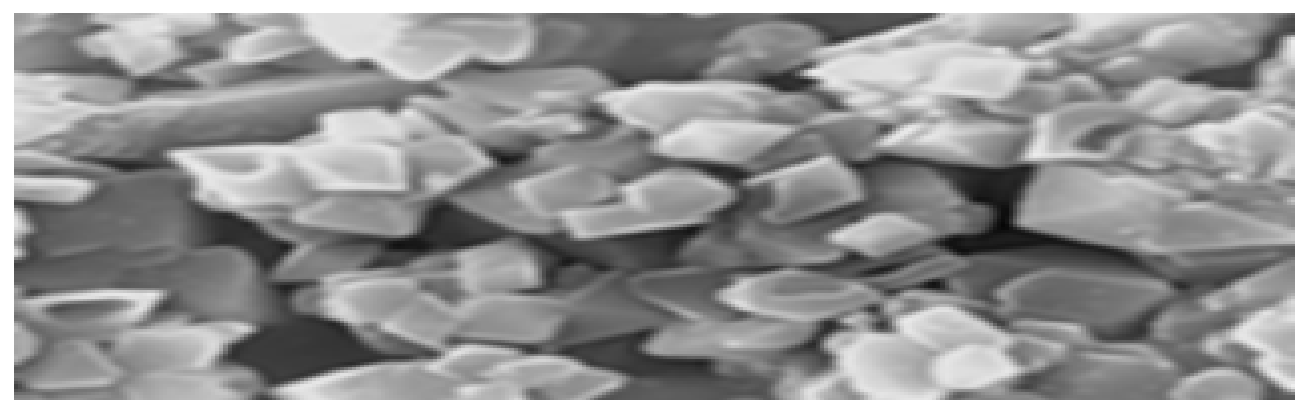

a)

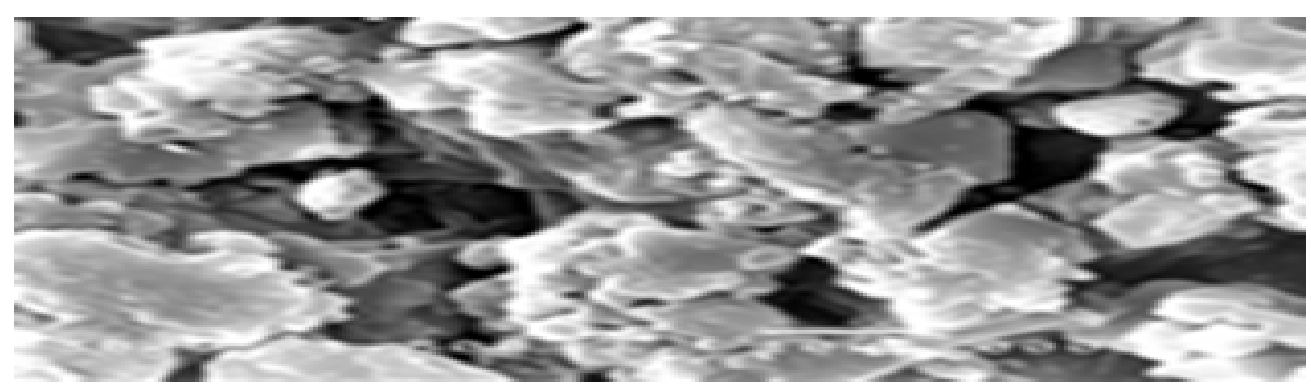

b)

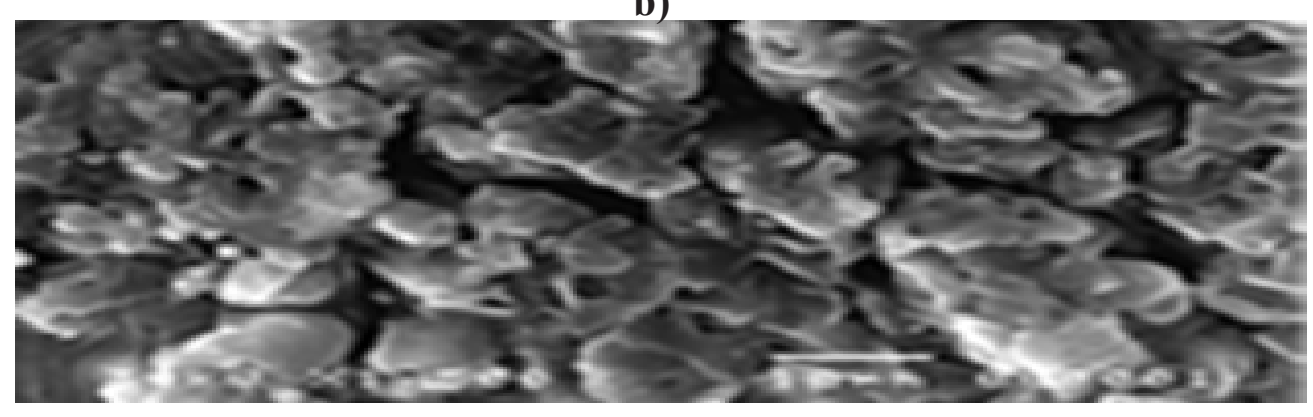

c)

Fig. 4. Scanning electron microscope of phosphorylated poly (vinyl alcohol)/ phosphorylated (poly acrylamide) and $0.3 \%$ carbon nano-wire at $10 \mathrm{kGy}$ gamma irradiation dose. a) Phosphorylated PVA: Phosphorylated PAAm (70:30\%), b) Phosphorylated PVA: Phosphorylated PAAm (80:20\%), c) Phosphorylated PVA: Phosphorylated PAAm (90:10\% by weight.

Egypt. J. Chem. 60, No. 5 (2017) 


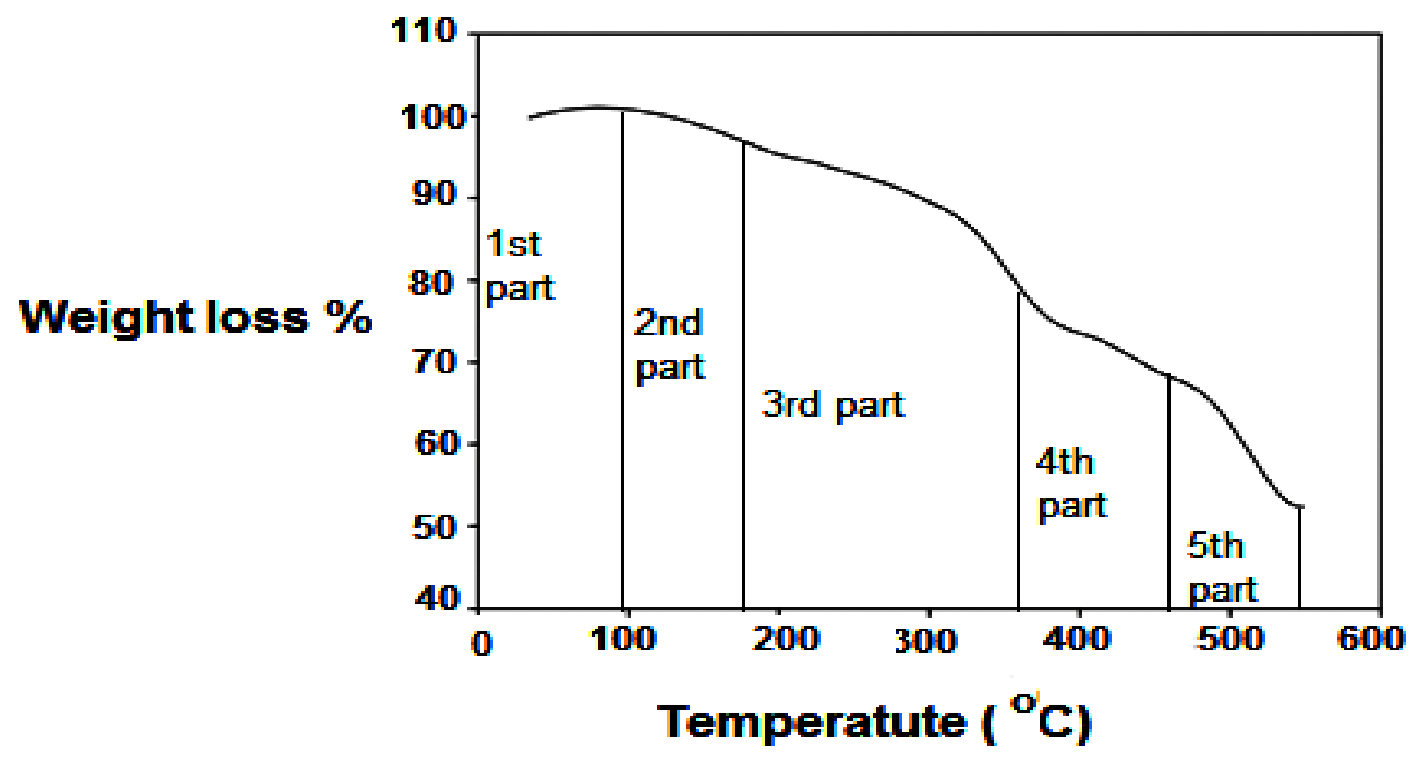

Fig. 5. Thermogram of $\mathbf{9 0 \%}$ phosphorylated poly (vinyl alcohol): $\mathbf{1 0 \%}$ phosphorylated poly (acrylamide) with $0.3 \%$ carbonnano-wire at $10 \mathrm{kGy}$ gamma irradiation dose.

TABLE 1. Thermogram results characterization.

\begin{tabular}{ccc}
\hline \multirow{2}{*}{ Thermograms divisions } & Temperature range ${ }^{\circ} \mathrm{C}$ & Weight loss \% \\
Part I & (Ambient) -98 & $\mathbf{4 6 \%}$ Grafting yield \\
Part II & $98-180$ & 0 \\
Part III & $180-360$ & 4 \\
Part IV & $360-460$ & 20 \\
Part V & $460-560$ & 30 \\
\hline
\end{tabular}

The first part described the membrane stability upon raising the temperature (the membrane working temperature) at which, no weight loss have been noticed. Hence, this drying step, namely the evaporation of moisture where the temperature range was under $100{ }^{\circ} \mathrm{C}$ [39]. Second part showed increasing the weight loss to $4 \%$ by raising the temperature range up to $180{ }^{\circ} \mathrm{C}$. It displayed tiny mass loss, which could be due to the loss of light volatiles [40]. Third part illustrated decrease $20 \%$ of the original weight that was described as active pyrolysis region, and most of the mass loss associated with the degradation of organics and in sequence [41]. The fourth part showed $10 \%$ loss weight as raising up the temperature to 460 ${ }^{\circ} \mathrm{C}$. The fifth part illustrated the weight decrease $16 \%$ by raising the temperature to $560^{\circ} \mathrm{C}$. Hence, the shoulder was not obvious in the sample, decomposition process described as, like tails. In the final stage, the residues were carbonized into stable and complex organic [42].

Membranes characterizations for using in the fuel cell

Characterizations of the phosphorylated PVA/phosphorylated PAAm with different ratios and $0.3 \%$ carbon nano-wire to investigate their availability into PEMFC were performed and tabulated in Table 2. 
TABLE 2. Casted membranes characterization compared to Nafion-1110.

\begin{tabular}{|c|c|c|c|c|c|c|c|}
\hline No. & $\begin{array}{c}\text { Kinds of } \\
\text { membranes }\end{array}$ & $\begin{array}{l}\text { Thickness } \\
\text { (mm) }\end{array}$ & $\begin{array}{c}\text { Water } \\
\text { uptake }(\%)\end{array}$ & $\begin{array}{c}\text { Ion Exchange } \\
\text { Capacity } \\
\left(\mathrm{mmolg}^{1}\right)\end{array}$ & $\begin{array}{c}\text { Proton } \\
\text { conductivity } \times 10^{2} \\
\left(\mathrm{Scm}^{1}\right)\end{array}$ & $\begin{array}{c}\text { Free volumes } \\
\text { size } \AA\end{array}$ & $\begin{array}{c}\text { Tensile at break } \\
\text { Strength (MPa) }\end{array}$ \\
\hline $1-$ & $\begin{array}{c}70 \% \text { PVA casted } \\
\text { membrane }\end{array}$ & 50 & 43 & 1.17 & 7.9 & 9.053 & 21 \\
\hline $3-$ & $\begin{array}{c}90 \% \text { PVA casted } \\
\text { membrane }\end{array}$ & 50 & 66 & 1.46 & 9.6 & 9.094 & 39 \\
\hline
\end{tabular}

Some parameters such as water uptake, IEC, proton conductivity, free volume sizes and tensile strength as a function of phosphorylated PVA ratio into the casted membranes (as a predominant factor to attain the optimum compatibility) were studied. Water uptake and IEC increased as phosphorylated PVA ratio increased. It was due to increase the phosphorylation yields, hydroxyl one and the more membrane compatibility. Proton conductivity increased with increasing the phosphorylated PVA ratio while at a high ratio $(90 \%)$ their value became constant. The significantly high proton conductivities of the casted multilayer membranes were due to high water content retention [28].

PALS is an important method for studying subnanometer size holes and for the determination of their size distribution and free-volume fractions [43]. The very important point of interest is the size of the nano-holes, which is strongly correlated with the o-Ps (ortho positron spectroscopy) lifetime. Since it had no information about nanohole shape, it is assumed that the nano-holes in the prepared membranes were spherical. According to the classical free-volume theory, the segmental motion of polymers is considered to incessantly generate and dissipate free-volume nano-holes [43]. The penetrant molecules in polymers can diffuse when they find neighboring holes large enough to move. It has been recognized that $D$ (molecules diffusion) of penetrants in polymers is affected by $\mathrm{rV}$ (gas constant) and other parameters revealed that $D$ in polymers strongly depended on the individual nano-hole size, $V$, measured by $P A L S$. It can be proposed the following empirical relationship between $D$ and $V$ is as follows:

$$
D=A R T \exp \left(-\frac{B}{V}\right) \ldots \ldots(4)
$$

where $A$ and $B$ denote the constants related to the types of gasses and polymers [44].

Phosphorylated PVA up to $90 \%$ revealed an increase in membranes free volumes. The porous membranes had strong ability to enhance $\mathrm{H}^{+}$diffusion and so increasing the ion exchange capacity, water uptake, and proton conductivity. Increasing pores numbers and their volumes onto the membranes enhanced $\mathrm{H}^{+}$exchanging capacity and so increasing proton conductivity. The uniformly dispersed molecules, (especially for $90 \%$ phosphorylated PVA casted membranes) could form bridges among functional groups ( a hydroxyl, $-\mathrm{PO}_{2}$ and an amine) clusters and shorten the distance for proton hopping under high humidity [28]. It can be strengthened by adding carbon nano-wire. The incorporation of carbon nano-particles into the prepared membranes materials contributed to a better filler interaction due to the fact that it facilitated the gap between the membranes components structures. It leads to an infinite conductive path development that aided in increasing electrical conductivity and better formation of the conducting network [45-47].

The conductivity via membranes is depending mainly on an ion exchanging process. The electrons motion is not the main process as the carbon nanowire low concentration which seemed as isolated islands.

For these reasons, phosphorylated PVA and carbon nanowire contained into the casted membranes raised the proton conductivity values and confirmed their utility for the fuel cell application. The casted membranes (90\% phosphorylated PVA $/ 10 \%$ phosphorylated PAAm) tensile strength showed more value compared to Nafion-1110. It was found that; the 
tensile strength at less than $90 \%$ phosphorylated PVA cast membranes decreased which may be due to less compatibility of the polymers shared into the casted membranes. These results appreciated using 90\% phosphorylated PVA cast membranes into the PEMFC.

\section{Fuel cell performance}

The PEMFC performance was carried out using Nafion 1110 and 90:10\% phosphorylated PVA / phosphorylated AAm with $0.3 \%$ carbon nano-wire cast membrane.

Figure $6 \& 7$ showed the polarization and performance curves for the PEMFC at $100 \%$ $\mathrm{RH}$ and $80{ }^{\circ} \mathrm{C}$ with $\mathrm{H}_{2}$ as a fuel and $\mathrm{O}_{2}$ as an oxidant under ambient pressure. From the data, it can be seen that prepared membrane showed better performance than Nafion 1110. Higher open-circuit voltages (OCVs) observed for the understudied membranes indicating that there are no problems related to gas permeability and no significant electronic conductivity which would otherwise adversely affected the OCV. The trends observed in polarization plot were in akin to the proton conductivity and IEC measurements for the membranes. In the prepared membranes, the proton conductivity is account for the transfer of protons through hydrogen bonding with waterfilled ion pores. The high density of $-\mathrm{PO}_{2}$ groups of the cast membrane act as a solid acid proton conducting medium which provides potential proton conducting sites, and facilitates achieving higher proton conductivity [48]. However, for Nafion 1110 membrane, lower in proton conduction and performance is observed. A large fuel cell performance at high current density region is clearly seen for the prepared membrane and Nafion1110. From the foregoing, it is obvious that the understudied membranes' performance is closely related to the issue of water management. The limited availability of water at the anode may be due to an electro-osmotic drag of water from the anode to the cathode and insufficient water back-diffusion from the cathode to the anode cause the MEA to dehydrate. Membrane dehydration resulted in an increase in the ohmic resistance of the cell, leading to decreasing in cell performance. By contrast, if the membranes hold more generated water and help the membranes sufficiently wet which maintains the proton conductivity value and enhances the power density. At high load current densities, water generation rates at the cathode are high enough to substantially affect the effective area of the gas-diffusion layers inside the electrode and cause flooding in the understudied membranes. However, high water uptake nature especially of the prepared membrane resulted in water is back diffused towards the anode electrode and maintains reasonable hydration level across the membrane and mitigates the cathode flooding [49].

The highest open circuit voltages were 0.90 $\mathrm{V}$ for Nafion 1110 and cast membrane at $80{ }^{\circ} \mathrm{C}$. The carbon nano-wire favor the mass transport (minimize gas crossover through the plane of the membrane) and reduce power losses when using the casted membranes. These facts increase effectively the membrane durability. At low current densities (up to $100 \mathrm{~mA} \mathrm{~cm}^{-2}$ ), when the fuel cell is a kinetic controlled both membranes showed nearly the same power densities, at a higher current densities the performance of the casted membrane became higher than the Nafion 1110 membrane [50].

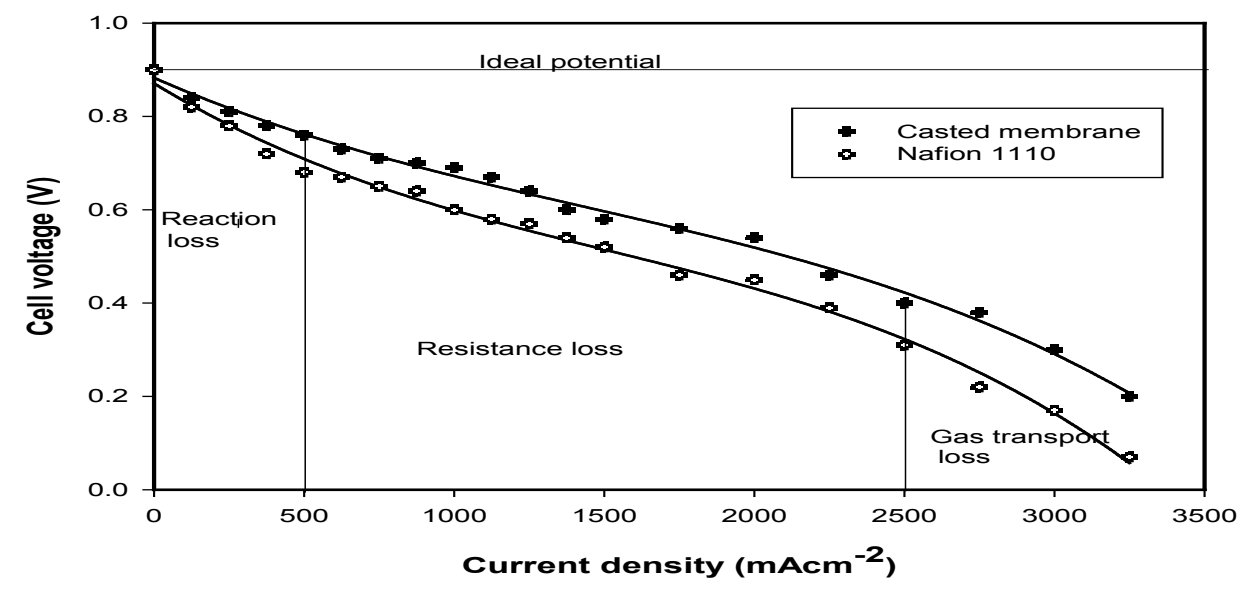

Fig. 6. Cell performance (current densities against voltage) of $90 \%$ phosphorylated poly (vinyl alcohol)/ phosphorylated poly (acrylamide) with $0.3 \%$ carbon nanowire casted membrane and Nafion-1110 at 80 OC temperature and $100 \% \mathbf{R H}$.

Egypt. J. Chem. 60, No. 5 (2017) 


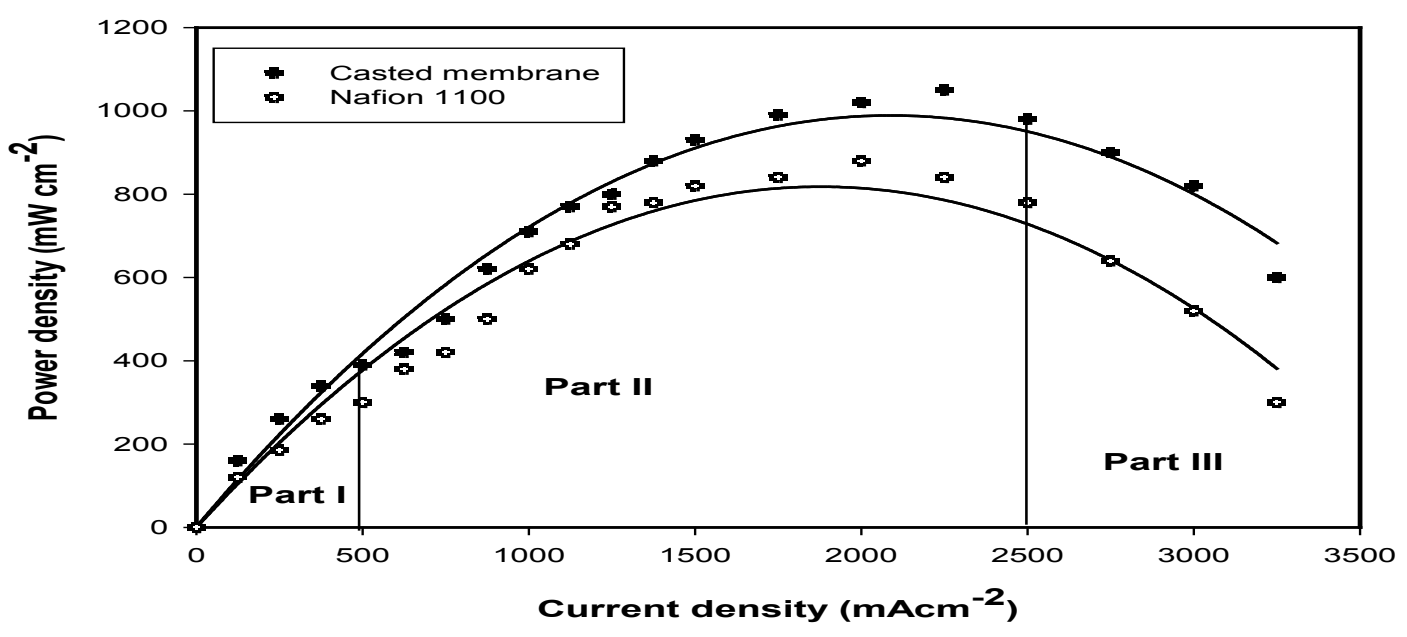

Fig. 7. Cell performance (current densities against power density) of $\mathbf{9 0 \%}$ phosphorylated poly (vinyl alcohol)/ phosphorylated poly (acrylamide) with $0.3 \%$ carbon nano-wire casted membrane and Nafion 1110 at $800 \mathrm{C}$ and $100 \%$ RH.

\section{Fuel cell durability}

The durability of the casted membrane (10\% phosphorylated PAAm with phosphorylated PVA and $0.3 \%$ carbon nanowire) and Nafion-1110 was performed and illustrated in Fig. 8.
The results showed that the $10 \%$ phosphorylated PAAm cast membranes slowed their rate of degradation compared to the compressed Nafion 1110 used. The polymer membrane degradation is likely to be the one mostly

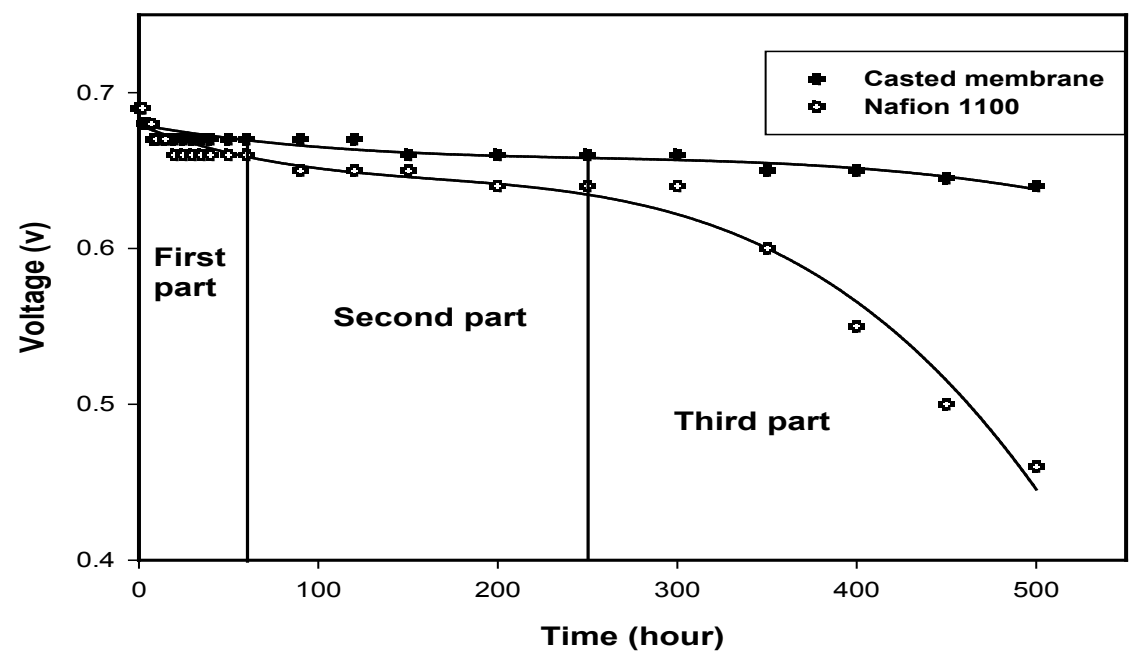

Fig. 8. Cell potential changes with time at fixed current density $(600 \mathrm{~mA} / \mathrm{cm} 2)$ for $90 \%$ phosphorylated poly (vinyl alcohol) / phosphorylated poly (acrylamide) with $0.3 \%$ carbon nano-wire casted membrane and Nafion-1110 at 80 oC and $100 \%$ RH. 
responsible for the failure of the PEMFC [51]. Mechanical and thermal membrane degradations could be mentioned [52], however they have a little effects on the fuel cell performances evolution during operation, except at the very end of the cell lifetime when its permeation current increases dramatically. It is a very sudden phenomenon which could be correlated also with the MEA initial fabrication defects and the bipolar plate mechanical constraints. Another critical degradation mechanism in PEMFC concerns is the catalyst layers and especially the active surface area loss during fuel cell operation. For instance, the irreversible losses can be due to carbon support corrosion, catalyst dissolution / re-deposition and catalyst layer micro-porous structure modification [53]. Conversely to the membrane degradation, these mechanisms affect directly the fuel cell performances with time but not directly a fuel cell failure. Degradation of Gas Diffusion Layers (GDL) and bipolar plates can also be observed but they seem to be a less.

A possible degradation mechanism was that; reactive species formed at the electrodes diffused into the polymer membrane and resulted in polymer chemical degradation. The OCV decay rates observed in this study are high, such values would be expected as membrane degradation due to the radical formation is enhanced under OCV operation and low relative humidity [54]. In the OCV durability test, the results are clear indications of the understudied membranes degradation decreased, which is most likely due to reduced release of harmful radicals formed at the anode. These radicals are believed to be captured by the active groups at the understudied membranes and become eliminated before they can attack the casted membrane material and cause the thinning and pinhole formation that are responsible for the increasing membrane permeability, and thereby gas crossover and OCV decay [55].

The reason for the fuel cell performance stability being improved with the casted membranes could be due to the final crosslinking restricting radicals' diffusion into the membranes matrix [28].

\section{Acknowledgment}

The authors wish to sincerely thank the STDF of Egypt, (ID220), for financially supporting this project.

\section{Conclusion}

This work aims to synthesize low cost and efficient polymer membranes used in proton exchangemembranefuelcell(PEMFC).Acrylamide phosphorylation was performed and mixed with phosphorylated PVA to prepare the cast composite. 0.3 carbon nanowire was inserted into the cast mixture for membrane reinforcement, gas passage control and has a role for the excess of hydrogen proton sorption. The cast mixture was irradiated with different doses (10 and $20 \mathrm{KGy}$ ) for finally crosslinking and ensure complete phosphorylation. Characterization of the membranes using FTIR, TGA, and SEM recommend their usage in PEMFC application. Measurements of some impacts such as water uptake, IEC and hardness were carried out. Proton conductivity and porosity (evaluated by $P A L S$ ) investigations confirmed the membranes utility into the fuel cell. The casted membrane at 90\% phosphorylated PVA has high performance and durability compared to compressed Nafion 1110 which recommend it to be successfully applied at the PEMFC.

\section{References}

1. Service, R.F., Shrinking fuel cells promise power in your pocket. Science. 296, 1222-1224 (2002).

2. Dillon, R., Srinivasan, S., Arico, A .S, Antonucci, V., International activities in DMFC R\&D: status of technologies and potential applications. J. Power Sources, 127, 112-126 (2004).

3. Neburchilov, V., Martin, J., Wang, H., Zhang, J., A review of polymer electrolyte membranes for direct methanol fuel cells. J. Power Sources, 169, 221-238 (2007).

4. Kim, J., Chung, K., Lee, H., Bae, B., Cho, EunBum Mesoporous ceria-silica/poly(arylene ether sulfone) composite membranes for durability of fuel cell electrolyte membrane. Microporous and Mesoporous Materials, 236, 292-300 (2016).

5. Molla, S., Compan, V., Gimenez, E, Blazquez, A., Urdanpilleta, I., Novel ultrathin composite membranes of Nafion/PVA for PEMFCs. Int. J. Hydrogen Energy, 36, 9886-95 (2011).

6. Akbarian-Feizi, L., Mehdipour-Ataei, S., Yeganeh H., Survey of sulfonated polyimide membrane as a good candidate for nafion substitution in fuel cell. Int. J. Hydrogen Energy, 35, 9385-97 (2010).

7. Bonifcio, R. N., Paschoal ,J.O.A., Linardi, M., 
Cuenca, R., Catalyst layer optimization by surface tension control during ink formulation of membrane electrode assemblies in proton exchange membrane fuel cell. J. Power Sources, 196, 4680-5 (2011).

8. Bose, A.B., Shaik, R., Mawdsley, J., Optimization of the performance of polymer electrolyte fuel cell membrane electrode assemblies: roles of curing parameters on the catalyst and ionomer structures and morphology. J. Power Sources, 182, 61-5 (2008).

9. Wang, L., Husar, A., Zhou, T., Liu, H., A parametric study of PEM fuel cell performances. Int. J. Hydrogen Energy, 28, 1263-72 (2003).

10. Yan, X., Hou, M., Sun, L., Liang, D., Shen, Q., $\mathrm{Xu}, \mathrm{O}$., et al., AC impedance characteristics of a 2 kW PEM fuel cell stack under different operating conditions and load changes. Int. J. Hydrogen Energy, 32, 4358-64 (2007).

11. Wasterlain, S., Candusso, D., Hissel, D., Harel, F., Bergman, P., Menard, P., et al., Study of temperature, air dew point temperature and reactant flow effects on proton exchange membrane fuel cell performances using electrochemical spectroscopy and voltammetry techniques. J. Power Sources, 195, 984-93 (2010).

12. Halake K., Birajdar M., Kim B. S., Bae H., Lee C. C., Kim Y. J., Kim S., Kim H. J., Ahn S., An S. Y. , Lee, Recent application developments of water-soluble synthetic polymers. J. Ind. Eng. Chem., 20, 39133918 (2014).

13. Premakshi, H.G., Ramesh, K., Kariduraganavar M. Y., Aminabhavi T. M., Modification of crosslinked chitosan membrane using $\mathrm{NaY}$ zeolite for pervaporation separation of water-isopropanol mixtures. Chem. Eng. Res. Des., 94, 32-43 (2015).

14. Bano, S., Mahmood, A., Kim, S.J, Lee, K.H., Chlorine resistant binary complexed NaAlg/PVA composite membrane for nanofiltration. Sep. Purif. Technol., 137, 21-27 (2014).

15. Sajjan, A.M., Premakshi, H.G., Kariduraganavar, M.Y., Synthesis and characterization of GTMAC grafted chitosan membranes for the dehydration of low water content isopropanol by pervaporation. $J$. Ind. Eng. Chem., 25,151-161 (2015).

16. Blanco, M.D., Garcia, O., Olmo, R., Teijon, J. M., Katime, I., Release of 5-fluorouracil from poly (acrylamide-co-monopropyl itaconate) hydrogels, $J$. Chromatogr. B. Biomed. Appl., 680, 243-253 (1996).

17. Chen, J., Haesun, P., Park, K., Synthesis of super- porous hydrogels: hydrogels with fast swelling and superabsorbent properties. J. Biomed. Mater. Res., 44, 53-62 (1999).

18. Ferreira, L., Vidal, M.M., Gil, M. H., Design of a drug-delivery system based on polyacrylamide hydrogels. Evaluation of structural properties, Chem. Educ., 6, 100-103 (2001).

19. Krusic, K.M., Dzunuzovic, E., Trifunovic, S., Filipovic, J., Semi-IPNs based on polyacrylamide and poly(itaconic acid), Polym. Bull., 51, 159-166 (2003).

20. Muniz, E.C., Geuskens, G., Compressive elastic modulus of polyacrylamide hydrogels and semi-IPNs with poly ( $\mathrm{N}$-isopropylacrylamide). Macromolecules, 34, 4480-4484 (2001).

21. Kuila, S.B., Ray, S.K., Paramita, Das, Singh, N.R., Synthesis of full interpenetrating network membranes of poly(acrylic acid-co-acrylamide) in the matrix of poly vinyl alcohol for dehydration of ethylene glycol by pervaporation. Chem. Eng. Process, 50, 391-403 (2011).

22. Singh D. J. V., Zhai L., Das S., Khondaker S. I., Seal S., Graphene based materials: past, present and future, Prog. Mater. Sci., 56, 1178-1271 (2011).

23. Chen P., Xu Y., He S., Sun X., Pan S., Deng J., Chen D., Peng H., Hierarchically arranged helical fibre actuators driven by solvents and vapours Nat. Nanotechnol., 10, 1077-1083 (2015).

24. De Volder M. F. L., Vansweevelt R., Wagner P., Reynaerts D., Hoof C. V., Hart A. J., Hierarchical carbon nanowire microarchitectures made by plasma-assisted pyrolysis of photoresist. ACS Nano, 5, 6593-6600 (2011).

25. Zhao Y., Grüner G., Nanonet as a scaffold with targeted functionalities. J. Mater. Chem., 22, 2498324991 (2012).

26. Wang X. R., Ouyang Y. J., Li X. L., Wang H. L., Guo J., Dai H. J., Room-temperature allsemiconducting sub-10-nm graphene nanoribbon field-effect transistors. Phys. Rev. Lett., 100 (2008).

27. Pupkevich V., Glibin V., Karamanev D., Phosphorylated polyvinyl alcohol membranes for redox $\mathrm{Fe}_{3} / \mathrm{H}_{2}$ flow cells. J. Power Sources, 228, 300-307 (2013).

28. El-Toony M.M., Abdel-Hady E.E., El-Kelsh N.A., Casting of poly hydroxybutarate/poly (vinyl alcohol) membranes for proton exchange fuel cells. Electrochim. Acta, 150, 290-297(2014).

Egypt. J. Chem. 60, No. 5 (2017) 
29. Ismail A. F., Zubir N., Nasef M. M., Dahlan K. M., Hassan A. R., Physicochemical study of sulfonated polystyrene pore-filled electrolyte membranes by electrons induced grafting. Memb. Sci. J., 254, 189196 (2005).

30. El-Toony M. M., Abdel-Hady E. E., and El-Kelesh N. A., Casting of poly (vinyl alcohol)/glycidyl methacrylate reinforced with titanium dioxide nanoparticles for proton exchange fuel cells. $J$. Solid State Electrochim., 20,1913-1920 (2016).

31. Liu, M., Shanshan, Chen, S., Ye, Y., Li J., Zhu, Q., Zhao, B., Zhao, W., X., Shen J., Biocompatible phosphonic acid-functionalized silica nanoparticles for sensitive detection of hypoxan thine in real samples. Talanta, 17, 536-542 (2013).

32. Abdel-Hady, E. E., El-Toony, M. M., Abdel-Hamed, M.O., Grafting of glycidyl methacrylate/styrene onto poly vinyldine fluoride membranes for proton exchange fuel cell. Electrochim. Acta, 103, 32- 37 (2013).

33. Olsen, J.V., Kirkegaard, P., Pedersen, N.J., Eldrup, M., PALS fit: a new program for the evaluation of positron lifetime spectra. Physica Status Solidi C, 4, 4004 (2007).

34. Walsby, N., Paronen, M., Juhanoja, J., Sundhoulm, F., Sulfonation of styrene grafted poly (vinylidene fluoride) films. Journal of Applied Polymer Science, 81, 1572-1580 (2001).

35. Jie-Cheng, T., Chien-Kung, L. Effect of PTFE content in gas diffusion layer based on Nafion/ PTFE membrane for low humidity proton exchange membrane fuel cell. Journal of the Taiwan Institute of Chemical Engineering, 42, 945-951 (2011).

36. Zenobi, M. C., Luengo, C.V., Avena, M. J., Rueda, E. H., An ATR-FTIR study of different phosphonic acids in aqueous solution. Spectrochim. Acta A Mol. Biomol. Spectrosc., 70(2), 270-6 (2008).

37. Dumitrescu, A.M., Lisa, G., Iordan A.R., Tudorache F., Petrila I., Borhan A. I., Palamaru M. N., Mihailescu C., Leontie L., Munteanu C., Ni ferrite highly organized as humidity sensors. Material Chem. Phys., 156, 170-179 (2015).

38. El-Toony, M.M., El-Kelesh, N.A., Abdel-Shafy, H.I., Synthesis and Characterization of PVA/ AAC Foam and their Application with Alum for Reduction of Turbidity, Calcium and Magnesium Ions, and Microbial Count in the Nile River, Water Journal, 3, 68-78 (2011).
39. Sharara, M., Sadaka, S., Thermo-gravimetric analysis of swine manure solids obtained from farrowing, and growing finishing farms. J. Sustain. Bioenergy Syst., 4, 75-86 (2014).

40. Munir, S., Daood, S. S., Nimmo, W., Cunliffe ,A. M., Gibbs, B. M., Thermal analysis and devolatilization kinetics of cotton stalk, sugar cane bagasse and shea meal under nitrogen and air atmospheres. Bioresour. Technol., 100, 1413-8 (2009).

41. Yang, H., Yan, R., Chen, H., Zheng, C., Lee, D. H., Liang, D. T. In-depth investigation of biomass pyrolysis based on three major components: hemicellulose, cellulose and lignin. Energy \& Fuels, 20, 388-93 (2006).

42. Zhang, Z., He, C., Sun, T., Zhang, Z., Song, K., Wu, Q., Zhang, Q., Thermo-physical properties of pretreated agricultural residues for bio-hydrogen production using thermo-gravimetric analysis. Inter. Hydrogen Energy, J. 41, 5234-5242 (2016).

43. Sawada, S., Yabuuchi, A., Maekawa, M., Kawasuso, A., Maekawa, Y., Location and size of nanoscale free-volume holes in crosslinkedpoly tetrafluoroethylene-based graft-type polymer electrolyte membranes determined by positron annihilation lifetime spectroscopy. Rad. Phys. Chem., 87, 46-52 (2013).

44. Tanaka, K., Kawai, T., Kita, H., Okamoto, K., Ito, Y., Correlation between gas diffusion coefficient and positron annihilation lifetime in polymers with rigid polymer chains. Macromolecules, 33, 5513-5517 (2000).

45. Fan, Z., Advani, S.G., Characterization of orientation state of carbon nanotubes in shear flow. Polymer, 46(14), 5232-40 (2005).

46. Taherian, R., Hadianfard, M.J., Golikand, A. N., Manufacture of a polymer-based carbon nanocomposite as bipolar plate of proton exchange membrane fuel cells. Mater. Des., 49, 242-51(2013).

47. Taherian, R., Hadianfard, M. J., Golikand, A. N., A new equation for predicting electrical conductivity of carbon-filled polymer composites used for bipolar plates of fuel cells. J. Appl. Polym. Sci., 128(3), 1497-509 (2013).

48. Liu, X. Y., Huang, M., Ma, H. L., Zhang, Z. Q., Gao, J. M., Zhu, Y. L., Han, X. J., Guo, X. Y., Preparation of a carbon-based solid acid catalyst by sulfonating activated carbon in a chemical reduction process. Molecules, 15, 7188-7196 (2010). 
49. Joseph, J., Tseng, C. Y., Hwang, B. J., Phosphonic acid-grafted meso structure dsi-lica/Nafion hybrid membranes for fuel cell applications. J. Power Sources, 196, 7363-7371 (2011).

50. Moreno, N. G., Gervasio, D., García, A. G., Robles J. F. P., Poly benzimidazole-multiwall carbon nanotubes composite membranes for polymer electrolyte membrane fuel cells. J. Power Sources, 300, 229-237(2015).

51. Dubau, L., Castanheira, L., Chatenet, M., Maillard, F., Dillet, J., Maranzana, G., Abbou, S., Lottin, O., Moor, G. D., Kaddouri ,A. E., Bas, C., Flandin, L., Rossinot, E., Caqu ,A. N., Carbon corrosion induced by membrane failure: the weak link of $\{$ PEMFC $\}$ long-term performance. Int. J. Hydrogen Energy, 39 (36), 21902-21914 (2014).

52. Jahnke, T., Futter, G., Latz, A., Malkow, T., Papakonstantinou G., Tsotridis G., Schott P., Gerard M., Quinaud M., Quiroga M., Franco A. A., Malek K., Calle- Vallejo F., de Morais R. F., Kerber T., Sautet P., Loffreda D., Strahl S., Serra
M., Polverino P., Pianese C., Mayur M., Bessler W. G., Kompis C., Performance and degradation of proton exchange membrane fuel cells: state of the art in modeling from atomistic to system scale. $J$ Power Sources, 304, 207-233 (2016).

53. Virkar, A.V., Zhou, Y., Mechanism of catalyst degradation in proton exchange membrane fuel cells. J. Power Sources, 154, B540-B547 (2007).

54.Wu, J., Yuan, X. Z., Martin ,J. J., Wang, H., Zhang, J., Shen, J., et al., A review of PEM fuel cell durability: degradation mechanisms and mitigation strategies. J. Power Sources, 184, 104-119 (2008).

55. Zaton, M., Jones, D., Roziere, J., Mitigation of PEM fuel cell electrolyte degradation with metal oxide/ nafion nanofiber interlayers, ECS Trans., 61, 15-23 (2014).

(Received 2/7/2017; accepted 20/8/2017)

\section{إستخدام طريقة الصب للأكريلاميد/بولي فينيل الكحول و المدعم بكربون نانووير و ذلك لإستعماله في خلايا طاقة البروتون المريلة المستبدل \\ محمد محرم التوني \\ هيئة الطاقة الذريةـ المركز القومي لبحوث و تكنولوجيا الإشعاع V ش احمد الزمر م.نصر ـ القاهرة ـ مصر.}

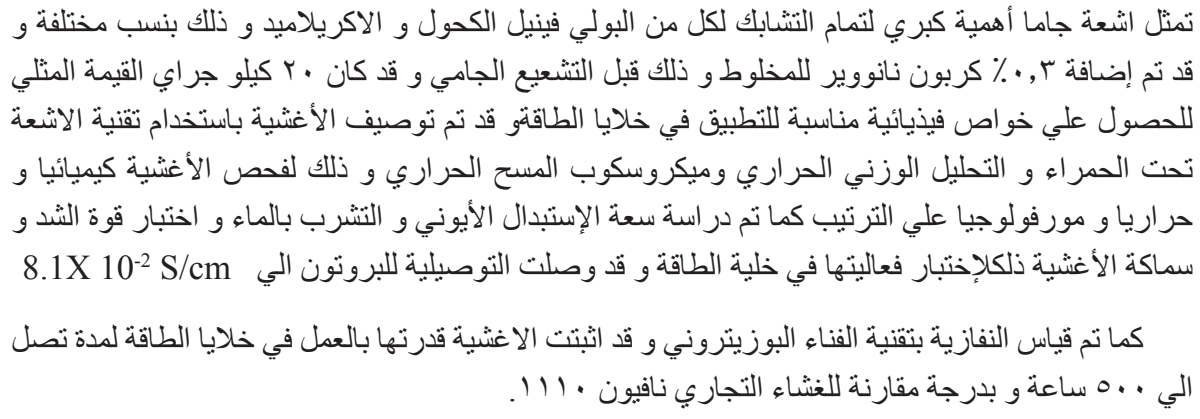

